\title{
PENERAPAN PENGEMBALIAN PENDAHULUAN KELEBIHAN PEMBAYARAN PAJAK PERTAMBAHAN NILAI DAN KAITANNYA DENGAN KEPATUHAN DAN PENERIMAAN PAJAK KPP PRATAMA BANGKINANG
}

\author{
Dana Ulfi Mahfuza* 1); Andri Marfiana ${ }^{2)}$ \\ 1) danaulfimhfz@gmail.com, Politeknik Keuangan Negara STAN \\ 2) andri.marfiana@pknstan.ac.id, Politeknik Keuangan Negara STAN
}

\begin{abstract}
The preliminary refund policy on overpayment of taxes that is not implemented by the provisions can harm the State and the Taxpayer. This study was conducted to determine the application of the prepayment of excess payment of Value Added Tax (VAT) and the effect it has on compliance and tax revenue of KPP Pratama Bangkinang. The method used is a mixed method that combines quantitative methods and qualitative methods with a descriptive approach. The results showed that the implementation of the preliminary refund carried out at the KPP Pratama Bangkinang was by the stipulated provisions. Although the prepayment of excess tax payments reduced the state treasury, this policy did not significantly affect the achievement of the tax revenue target. In addition, the implementation of this policy also encourages taxpayers' awareness to comply with their tax obligations.
\end{abstract}

Keywords : Value Added Tax, Tax Overpayment, Preliminary Return, Compliance, Tax Receipt

\begin{abstract}
Abstrak
Kebijakan pengembalian pendahuluan kelebihan pembayaran pajak yang tidak diterapkan sesuai dengan ketentuan dapat merugikan Negara maupun Wajib Pajak. Penelitian ini dilakukan untuk mengetahui penerapan pengembalian pendahuluan kelebihan pembayaran Pajak Pertambahan Nilai (PPN) dan pengaruh yang diberikan terhadap kepatuhan dan penerimaan pajak KPP Pratama Bangkinang. Metode yang digunakan adalah metode campuran yaitu menggabungkan metode kuantitatif dan metode kualitatif dengan pendekatan deskriptif. Hasil penelitian menunjukkan bahwa penerapan pengembalian pendahuluan yang dilakukan di KPP Pratama Bangkinang telah sesuai dengan ketentuan yang ditetapkan. Walaupun pengembalian pendahuluan kelebihan pembayaran pajak mengurangi kas negara, kebijakan ini tidak memengaruhi pencapaian target penerimaan pajak secara signifikan. Selain itu, penerapan kebijakan ini juga mendorong kesadaran Wajib Pajak untuk patuh menjalankan kewajiban perpajakannya.
\end{abstract}

Kata kunci : Pajak Pertambahan Nilai, Kelebihan Pembayaran Pajak, Pengembalian Pendahuluan,

Kepatuhan, Penerimaan Pajak

\section{PENDAHULUAN}

Pemerintah setiap tahunnya menetapkan target penerimaan pajak yang disampaikan dalam Anggaran Pendapatan dan Belanja Negara (APBN). Sebagai negara berkembang, Indonesia membutuhkan biaya yang besar untuk melaksanakan pembangunan. Hal ini memicu penetapan target penerimaan yang terus meningkat untuk mengoptimalkan pendapatan negara. Permasalahan yang terjadi adalah tidak tercapainya target penerimaan yang diakibatkan adanya perubahan target sebagaimana ditunjukkan dalam Tabel 1 di bawah ini.

Tabel 1 - Realisasi Penerimaan Pajak Tahun 2015-2019

\begin{tabular}{|c|c|c|c|c|c|}
\hline Tahun & & Target & & Realisasi & $\begin{array}{c}\text { Persentase } \\
\text { Pencapaian } \\
\text { Target }\end{array}$ \\
\hline 2015 & $\mathrm{Rp}$ & 1.489 .255 .488 .129 .000 & $\mathrm{Rp}$ & 1.240 .418 .857 .626 .370 & $83.29 \%$ \\
\hline 2016 & $\mathrm{Rp}$ & 1.539.166.244.581.000 & $\mathrm{Rp}$ & 1.284 .970 .139 .927 .480 & $83.48 \%$ \\
\hline 2017 & $\mathrm{Rp}$ & 1.472 .709 .861 .675 .000 & $\mathrm{Rp}$ & 1.343 .529 .843 .798 .510 & $91.23 \%$ \\
\hline 2018 & $\mathrm{Rp}$ & 1.618.095.493.162.000 & $\mathrm{Rp}$ & 1.518.789.777.151.030 & $93.86 \%$ \\
\hline 2019 & $\mathrm{Rp}$ & $\begin{array}{l}\text { 1.786.378.650.376.000 } \\
\text { Sumber : Laporan K }\end{array}$ & & $\begin{array}{l}1.546 .141 .893 .392 .190 \\
\text { n Pemerintah Pusat }\end{array}$ & $86.55 \%$ \\
\hline
\end{tabular}


Salah satu sumber penerimaan pajak pusat adalah Pajak Pertambahan Nilai (PPN). Undang-Undang Pajak Pertambahan Nilai Nomor 8 Tahun 1983 sebagaimana telah beberapa kali diubah terakhir dengan Undang-Undang Nomor 11 Tahun 2020 tentang Cipta Kerja menerangkan bahwa PPN dikenakan terhadap Pengusaha Kena Pajak (PKP) yang melakukan penyerahan dan/atau ekspor Barang Kena Pajak (BKP), Jasa Kena Pajak (JKP), maupun Barang Kena Pajak Tidak Berwujud (BKPTB). Selain itu, PPN juga dikenakan terhadap siapapun yang melakukan impor BKP serta pemanfaatan JKP dan BKPTB dari luar daerah pabean di dalam daerah pabean. Dalam transaksi yang mengandung PPN terdapat istilah pajak masukan dan pajak keluaran. Kedua hal tersebut diperhitungkan untuk mencari jumlah pajak terutang dengan mengkreditkan pajak masukan terhadap pajak keluaran.

Pengkreditan pajak masukan terhadap pajak keluaran tidak selalu menimbulkan kurangnya pembayaran PPN. Kadangkala pengkreditan tersebut menyebabkan kelebihan pembayaran pajak akibat jumlah pajak masukan yang lebih besar dibandingkan dengan jumlah pajak keluaran. Kelebihan pembayaran pajak tersebut dapat diminta kembali (restitusi) oleh Wajib Pajak kepada Direktorat Jenderal Pajak melalui Kantor Pelayanan Pajak (KPP) jika telah memenuhi syarat dan ketentuan yang telah ditetapkan.

Undang-Undang Ketentuan Umum dan Tata Cara Perpajakan Nomor 6 Tahun 1983 sebagaimana telah beberapa kali diubah terakhir dengan Undang-Undang Nomor 11 Tahun 2020 tentang Cipta Kerja menjelaskan bahwa terdapat dua mekanisme penyelesaian restitusi yaitu mekanisme umum dan mekanisme khusus. Mekanisme umum yang diatur dalam Pasal 17B, menerangkan penyelesaian restitusi dilakukan melalui proses pemeriksaan. Sedangkan mekanisme khusus, disebut juga dengan pengembalian pendahuluan, yang diatur dalam pasal 17C dan 17D, menjelaskan penyelesaian restitusi dilakukan melalui proses penelitian. Pengembalian pendahuluan berlaku bagi wajib pajak dengan kriteria tertentu, wajib pajak yang memenuhi persyaratan tertentu, dan Pengusaha Kena Pajak (PKP) berisiko rendah.

Peraturan Menteri Keuangan Nomor 39/PMK.03/2018 tentang Tata Cara Pengembalian Pendahuluan Kelebihan Pembayaran Pajak menyebutkan bahwa jangka waktu penyelesaian pengembalian pendahuluan PPN adalah paling lama 1 (satu) bulan. Jangka waktu penyelesaian ini lebih singkat dibandingkan dengan restitusi menggunakan mekanisme umum yaitu paling lama 12 (dua belas) bulan. Tujuan dari kebijakan ini antara lain sebagai bentuk pelayanan untuk memperbaiki likuiditas Wajib Pajak, terutama bagi para eksportir yang diharapkan mampu memacu kegiatan ekspor. Pembebasan pungutan PPN (0\%) terhadap ekspor menimbulkan potensi besar terhadap kelebihan pembayaran pajak yang dapat diminta kembali oleh Wajib Pajak (Pamungkas, 2019). Pemberian fasilitas ini seharusnya menjadi motivasi bagi Wajib Pajak untuk menjadi Wajib Pajak patuh.

Ada beberapa penelitian yang menganalisis pengaruh restitusi terhadap penerimaan. Antara lain penelitian yang dilakukan di KPP Pratama Manado, disebutkan bahwa restitusi PPN mempengaruhi penerimaan pajak yang mengakibatkan penerimaan pajak berkurang karena adanya penyaluran dana kepada Wajib Pajak (Supit dkk, 2014). Namun, hal ini berbanding terbalik dengan penelitian yang ada pada pada KPP Pratama Jakarta Penjaringan, bahwa restitusi PPN tidak memengaruhi penerimaan pajak (Riftiasari, 2019).

Kedua penelitian terdahulu yang memiliki hasil saling bertolak belakang tersebut dipengaruhi oleh perbedaan karakteristik wajib pajak yang dimiliki oleh masing-masing KPP. Selain itu, penelitian-penelitian tersebut meneliti mengenai penyelesaian restitusi PPN secara keseluruhan baik melalui mekanisme umum maupun melalui mekanisme khusus. Begitu pula dengan penelitian lainnya, penulis tidak menemukan penelitian mengenai restitusi yang berfokus kepada mekanisme khusus atau pengembalian pendahuluan.

Uraian di atas membuat penulis tertarik untuk melakukan penelitian mengenai penerapan restitusi PPN atas pengembalian pendahuluan dan kaitannya terhadap penerimaan 
pajak. Pengembalian pendahuluan bertujuan untuk memenuhi hak Wajib Pajak dan sebagai bentuk layanan untuk memperbaiki likuiditas wajib pajak. Walaupun penerimaan pajak memang merupakan hal yang krusial sebagai salah satu penyokong pembangunan negeri, bukan berarti pelayanan yang diberikan kepada Wajib Pajak dapat dikesampingkan.

Wajib Pajak dapat meminta kembali kelebihan pembayaran PPN melalui Kantor Pelayanan Pajak terdaftar. Salah satunya adalah KPP Pratama Bangkinang yang memberikan layanan pengembalian pendahuluan. Tujuan penelitian ini adalah mengetahui penerapan pengembalian pendahuluan kelebihan pembayaran PPN, mengetahui kepatuhan penyampaian SPT Masa PPN dan SPT Tahunan oleh PKP yang mendapatkan pengembalian pendahuluan kelebihan pembayaran PPN, dan mengetahui dan menganalisis pengaruh pengembalian pendahuluan kelebihan pembayaran pajak terhadap penerimaan pajak di KPP Pratama Bangkinang.

\section{KAJIAN PUSTAKA \\ Restitusi Pajak}

Undang-Undang Pajak Pertambahan Nilai Nomor 8 Tahun 1983 sebagaimana telah beberapa kali diubah terakhir dengan Undang-Undang Nomor 11 Tahun 2020 tentang Cipta Kerja, disebut juga dengan UU PPN, mengatur pengenaan PPN menggunakan metode kredit pajak dengan melakukan pengkreditan Pajak Masukan terhadap Pajak Keluaran. Hal ini sebagai upaya penghindaran adanya pengenaan pajak berganda karena pemungutan PPN yang dilakukan pada setiap transaksi mulai dari produksi hingga distribusi (Mardiasmo, 2018).

Mekanisme pengkreditan Pajak Masukan terhadap pajak keluaran menyebabkan adanya selisih. Selisih ini berasal dari pembayaran antara jumlah PPN yang dipungut dengan yang dibayarkan oleh Wajib Pajak yang merupakan PKP. Atas selisih yang menyebabkan adanya kekurangan pembayaran PPN, Wajib Pajak wajib melunasi kekurangan pembayaran tersebut, sedangkan atas selisih yang menyebabkan adanya kelebihan pembayaran PPN, Wajib Pajak dapat mengkompensasikan kelebihan pembayaran tersebut ke masa pajak berikutnya atau meminta kelebihan yang dikenal dengan sebutan restitusi (Octavia dkk, 2015). Undang-Undang Nomor 6 Tahun 1983 tentang Ketentuan Umum dan Tata Cara Perpajakan dan perubahannya, disebut juga dengan UU KUP, mendefinisikan restitusi pajak sebagai hak wajib pajak untuk meminta kembali besaran kelebihan pembayaran pajak akibat pajak masukan yang dapat dikreditkan lebih besar dibandingkan dengan pajak keluaran.

\section{Faktor-faktor Terjadinya Kelebihan Pembayaran Pajak}

Darussalam dkk (2018) mengelompokkan penyebab terjadinya kelebihan pembayaran pajak menjadi 3 bagian yang mengacu pada ketentuan perundang-undangan.

1. Berdasarkan pasal 9 ayat (4a) UU PPN, besaran pajak keluaran yang lebih kecil dibandingkan dengan pajak masukan yang disebabkan oleh keadaan berikut:

a. PKP melakukan kegiatan ekspor,

b. PKP melakukan penyerahan BKP atau JKP kepada pemungut PPN,

c. PKP melakukan penyerahan BKP atau JKP yang mendapatkan fasilitas PPN tidak dipungut,

d. pembelian BKP berupa barang modal saat Pengusaha Kena Pajak belum mulai beroperasi sehingga belum terdapat kegiatan penyerahan yang terutang PPN, dan

e. keadaan lain yang menyebabkan jumlah pajak keluaran lebih kecil dibandingkan dengan pajak masukan dalam suatu masa pajak.

2. Berdasarkan pasal 17 ayat (2) UU KUP, pemungutan yang tidak benar mengakibatkan:

a. PPN yang dipungut lebih besar dari yang seharusnya terutang, misalnya dikarenakan kesalahan perhitungan atau penetapan DPP PPN; atau 
b. pemungutan PPN yang seharusnya tidak dipungut, misal pada BKP/JKP yang mendapatkan fasilitas tidak dipungut.

3. Berdasarkan pasal 16e UU PPN, pembelian barang di dalam daerah pabean oleh orang pribadi yang bukan merupakan subjek pajak dalam negeri dan dikonsumsi di luar daerah pabean.

\section{Pengembalian Pendahuluan Kelebihan Pembayaran Pajak}

Pengembalian pendahuluan kelebihan pembayaran pajak diselesaikan dalam jangka waktu yang lebih singkat dibandingkan dengan mekanisme umum yang dilakukan melalui pemeriksaan selama 12 bulan (Darussalam dkk, 2018). Kegiatan pemeriksaan ini dianggap menyita waktu bagi pemeriksa dan juga Wajib Pajak, sedangkan keputusan pemberian restitusi diharapkan dilakukan dengan cepat dan tepat waktu karena hal ini memengaruhi cash flow PKP. Dengan mempertimbangkan hal tersebut, dibuatlah kebijakan pemberian pengembalian pendahuluan yang diselesaikan melalui penelitian selama 1 (satu) bulan. Kebijakan ini merupakan upaya yang diberikan Direktorat Jenderal Pajak dalam rangka melayani Wajib Pajak sebagai pemenuhan hak Wajib Pajak. Adanya kebijakan ini diharapkan Wajib Pajak dapat meningkatkan kepatuhan dalam menjalankan kewajiban perpajakannya (Silvia dkk, 2014).

Pengembalian pendahuluan diberikan apabila seluruh ketentuan dan persyaratan telah terpenuhi, baik secara formal maupun material. Apabila disetujui, Direktorat Jenderal Pajak akan menerbitkan Surat Keputusan Pengembalian Pendahuluan Kelebihan Pajak (SKPPKP) untuk Wajib Pajak. Pengembalian pendahuluan kelebihan pembayaran pajak ini diperuntukkan bagi wajib pajak dengan kriteria tertentu, persyaratan tertentu, dan PKP berisiko rendah (Darussalam dkk, 2018).

\section{Kepatuhan Wajib Pajak}

Kepatuhan pajak merupakan pemahaman ketentuan peraturan perpajakan oleh Wajib Pajak ketika mengisi formulir pajak dengan lengkap, benar, dan jelas, menghitung pajak terutang dengan benar, serta membayar dan melaporkan pajak tepat waktu. Kepatuhan Wajib Pajak dapat dipengaruhi oleh faktor internal dan faktor eksternal. Faktor internal berkaitan dengan karakteristik Wajib Pajak yang memicu kepatuhan menjalankan kewajiban perpajakan. Sedangkan faktor eksternal berasal dari lingkungan Wajib Pajak (Cindy \& Yenni, 2013).

\section{Penerimaan Pajak}

Pemerintah terus mengupayakan penerimaan negara dengan melakukan perluasan sumber penerimaan di berbagai sektor (Christoper \& Rondonuwu, 2016). Salah satunya penerimaan yang memiliki potensi besar adalah pajak. Pajak mendukung kinerja pemerintah dalam pembangunan negara sehingga tujuan pemerintah dapat tercapai (Suharyono, 2019). Undang-Undang Pasal 1 angka 3 Nomor 4 Tahun 2012 tentang Perubahan atas Undang-Undang Nomor 22 Tahun 2011 Tentang Anggaran Pendapatan dan Belanja Negara Tahun Anggaran 2012 mendefinisikan penerimaan pajak sebagai penerimaan negara yang bersumber dari pajak dalam negeri dan pajak perdagangan internasional.

Direktorat Jenderal Pajak memiliki tugas utama untuk menghimpun penerimaan negara. Di sisi lain, para petugas pajak juga memiliki kewajiban untuk memberikan pelayanan kepada Wajib Pajak. Kebijakan restitusi ini merupakan salah satu bentuk pelayanan yang diberikan kepada Wajib Pajak. Namun, hal ini menjadi dilema karena restitusi dianggap sebagai pengeluaran dana pada kas negara yang dapat memberikan potensi kerugian (Yanis, 2011, sebagaimana dikutip dalam Silvia dkk, 2014). 


\section{Penelitian Terdahulu}

Supit et al. (2014) mengungkapkan bahwa restitusi memberikan pengaruh negatif terhadap penerimaan Pajak Pertambahan Nilai. Hal ini mengakibatkan dana pajak berkurang karena adanya pengembalian dana ke Wajib pajak. Penelitian ini berfokus pada pengaruh restitusi yang terjadi terhadap penerimaan Pajak Pertambahan Nilai. Perbedaan dengan penelitian ini adalah penulis berfokus pada restitusi dengan mekanisme pengembalian pendahuluan dan pengaruhnya terhadap penerimaan pajak yang ada pada Kantor Pelayanan Pajak. Jusmani \& Qurniawan (2016) dengan penelitian menjelaskan mengenai persentase Pengusaha Kena Pajak yang mengajukan restitusi dan hal-hal yang menyebabkan restitusi. Perbedaan dengan yang diteliti adalah penulis mengungkapkan kepatuhan pelaporan SPT Masa PPN oleh Pengusaha Kena Pajak yang diberikan restitusi dengan mekanisme pengembalian pendahuluan.

Nuraisyah (2019) penelitiannya berfokus pada implementasi pemberian pengembalian pendahuluan kelebihan pembayaran pajak di KPP Pratama Malang Utara. Perbedaan dengan yang dilakukan oleh penulis adalah berfokus pada efektivitas penerapan pengembalian pendahuluan yang terjadi di KPP Pratama Bangkinang. Riftiasari (2019) dalam penelitiannya mengungkapkan bahwa restitusi tidak mempengaruhi penerimaan Pajak Pertambahan Nilai. Selain itu penelitian tersebut juga mengungkapkan prosedur restitusi berdasarkan (Standard Operating Procedures) yang berlaku. Perbedaan dengan yang diteliti adalah penulis berfokus pada penerapan restitusi dengan mekanisme pengembalian pendahuluan dan kaitannya dengan penerimaan pajak yang ada.

Anjarwi \& Kharisma (2021) dalam penelitiannya mengungkapkan perbandingan ketentuan restitusi yang lama dengan ketentuan restitusi yang baru (percepatan restitusi). Penelitian tersebut menganalisis pengaruh banyaknya jumlah percepatan restitusi Pajak Pertambahan Nilai terhadap penerimaan Pajak Pertambahan Nilai. Perbedaan dengan penelitian ini adalah penulis berfokus pada jumlah restitusi mekanisme pengembalian pendahuluan dengan ketentuan lama (tanpa percepatan) dan pengaruhnya terhadap penerimaan pajak.

\section{Landasan (Kriteria) untuk Melakukan Analisis atas Pengembalian Pendahuluan Kelebihan Pembayaran Pajak}

Permasalahan yang menjadi objek penulisan ini adalah penerapan pengembalian pendahuluan kelebihan pembayaran Pajak Pertambahan Nilai. Pemberian restitusi atas kelebihan pembayaran pajak merupakan bentuk pelayanan sebagai pemenuhan hak Wajib Pajak. Kebijakan ini diberikan payung hukum untuk memberikan ketegasan dan rasa aman dalam praktik pelaksanaannya.

Adanya penerapan kebijakan pelayanan ini membuat beberapa aspek perlu ditinjau kembali. Pertama, penerapan pengembalian pendahuluan kelebihan pembayaran pajak harus sesuai dengan ketentuan dan aturan yang berlaku. Adapun kendala yang dihadapi harus dapat diselesaikan dengan bijak dan profesional. Perlu ditinjau apakah pengembalian pendahuluan yang diterapkan telah sesuai dengan ketentuan yang telah ditetapkan, karena kesalahan ataupun kelalaian dalam penerapannya dapat merugikan negara ataupun Wajib Pajak.

Kedua, kebijakan pengembalian pendahuluan memiliki tujuan utama untuk melindungi cash flow dan menjaga likuiditas Wajib Pajak. Hal ini tentu menguntungkan Wajib Pajak, terutama para eksportir. Adanya pengembalian pendahuluan diharapkan mampu mendorong kesadaran Wajib Pajak untuk patuh menjalankan kewajiban perpajakannya, dalam hal ini kepatuhan pelaporan SPT Masa PPN.

Ketiga, atas setiap kebijakan pastinya memberikan pengaruh, baik pengaruh positif maupun pengaruh negatif. Adanya penyaluran dana kelebihan pembayaran pajak kepada Wajib Pajak tentu menyebabkan pengurangan pada kas negara. Perlu ditinjau seberapa besar pengaruh 
yang diberikan atas penerapan pengembalian pendahuluan terhadap penerimaan pajak yang diperoleh.

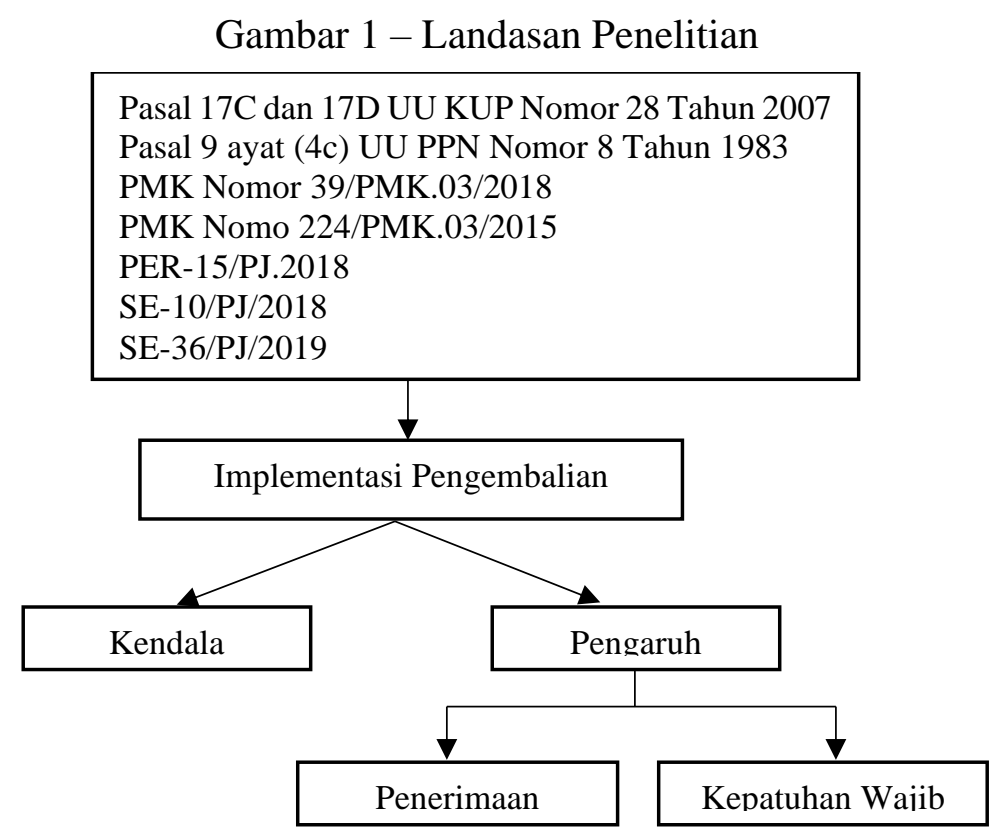

Sumber : Peneliti (2021)

\section{METODE}

Dalam penelitian ini penulis menggunakan metode campuran dengan menggabungkan metode kuantitatif dan metode kualitatif. Metode ini akan dilakukan dengan pendekatan deskriptif. Penulis menganalisis data dengan mendeskripsikan atau menggambarkan data yang telah ditemukan. Strategi penelitian yang digunakan adalah studi kasus pada Kantor Pelayanan Pajak (KPP) Pratama Bankinang dengan mengumpulkan berbagai data sekunder. Sebagai langkah awal pengumpulan data, penulis melakukan survei pendahuluan. Hal ini untuk mendapatkan kepastian mengenai informasi terkait objek penelitian dan untuk melihat kondisi tempat penelitian terkait penerapan pengembalian pendahuluan kelebihan pembayaran pajak yang dilaksanakan. Selain itu, survei pendahuluan juga dilakukan untuk memperoleh gambaran umum instansi. Penulis mengumpulkan data sekunder berupa dokumen terkait data-data yang dibutuhkan dengan melakukan wawancara kepada Pelaksana Seksi Pelayanan dan Account Representative di Seksi Pengawasan dan Konsultasi I terkait penerapan pengembalian pendahuluan kelebihan pembayaran pajak yang terjadi di KPP Pratama Bangkinang.

\section{HASIL DAN PEMBAHASAN}

\section{Penerapan Pengembalian Pendahuluan PPN di KPP Pratama Bangkinang}

Proses pengembalian pendahuluan kelebihan pembayaran PPN diselesaikan melalui beberapa tahap. Berdasarkan wawancara yang dilakukan kepada Account Representative (AR) pada Seksi Pengawasan dan Konsultasi I (Seksi Waskon I) dan Pelaksana Seksi Pelayanan, proses pengembalian pendahuluan kelebihan pembayaran pajak adalah sebagai berikut:

1. Wajib Pajak melaporkan SPT Masa PPN Lebih Bayar dengan mencentang Pengembalian Pendahuluan.

2. Seksi Pelayanan mengirimkan Nota Dinas SPT Lebih Bayar ke Seksi Pengawasan dan Konsultasi I. 
3. AR melakukan penelitian kewajiban formal dan penelitian material terhadap SPT Masa PPN Lebih Bayar sesuai dengan ketentuan yang berlaku.

4. Atas permohonan pengembalian pendahuluan tersebut wajib diberikan jawaban berupa penerbitan SKPPKP (Surat Keputusan Pengembalian Pendahuluan Kelebihan Pajak) atau tidak menerbitkan SKPPKP paling lama satu bulan sejak SPT Masa PPN disampaikan. Dalam hal wajib Pajak memenuhi kriteria yang telah ditentukan, maka diterbitkan SKPPKP. Sedangkan jika Wajib Pajak tidak memenuhi ketentuan, maka SKPPKP tidak diterbitkan dan SPT yang diajukan Wajib Pajak akan diproses melalui pemeriksaan.

5. Jika batas waktu keputusan atas permohonan pengembalian pendahuluan terlewat, maka permohonan pengembalian pendahuluan dianggap dikabulkan.

6. Satu hari kerja setelah SKPPKP diterbitkan, AR menerbitkan Surat Permintaan Rekening Dalam Negeri kepada Wajib Pajak. Wajib Pajak memenuhi permintaan tersebut paling lama lima hari kerja sejak tanggal Surat Permintaan Rekening Dalam Negeri dikirim ke Wajib Pajak. Namun, terkait batas waktu pemenuhan permintaan rekening tersebut, AR tetap menunggu hingga satu bulan sejak tanggal penerbitan SKPPKP.

7. Selanjutnya AR akan melakukan penelitian. Jika setelah dilakukan penelitian ternyata masih terdapat Pajak Masukan yang belum dilaporkan maka akan dilakukan koreksi, sehingga jumlah yang dapat dikabulkan hanya sebagian saja yaitu sebesar Pajak Masukan yang telah dilaporkan baik oleh Wajib Pajak sendiri maupun lawan transaksi.

8. Setelah dilakukan penelitian, AR akan membuat dan menyampaikan Nota Perhitungan Pengembalian Kelebihan Pembayaran Pajak dan Surat Keputusan Pengembalian Kelebihan Pembayaran Pajak (SKPKPP) ke Seksi Pelayanan untuk ditindaklanjuti. SKPKPP tersebut wajib diterbitkan paling lama satu bulan sejak diterbitkannya SKPPKP. Dalam hal Wajib Pajak tidak memberikan rekening, maka AR akan menerbitkan SKPKPP tanpa rekening.

9. SKPKPP yang telah dilengkapi dengan rekening dalam negeri selanjutnya akan diproses untuk menerbitkan SPMKP (Surat Perintah Membayar Kelebihan Pembayaran Pajak) oleh Pelaksana Seksi Pelayanan. Penerbitan SPMKP dilakukan paling lama lima hari kerja sejak SKPKPP diterbitkan atau sejak KPP menerima rekening dalam negeri atas nama Wajib Pajak dalam hal diterbitkan SKPKPP tanpa rekening.

10. Melalui persetujuan Kepala KPP, Pelaksana Seksi Pelayanan mencetak SPMKP melalui aplikasi SAKTI.

11. SPMKP yang telah ditandatangani oleh Kepala KPP dan SKPKPP selanjutnya dipindai dan diunggah pada aplikasi SAKTI. Setelah itu dilakukan inject PIN oleh Kepala KPP dan diteruskan ke KPPN (Kantor Pelayanan Perbendaharaan Negara) untuk dilakukan pencairan dana kelebihan pembayaran pajak kepada Wajib Pajak. Penerusan berkas ke KPPN dilakukan paling lama dua hari kerja sejak diterbitkannya SPMKP.

Dalam pelaksanaan proses permohonan pengembalian pendahuluan kelebihan pembayaran pajak, setiap seksi memiliki kendala yang berbeda.

Seksi Waskon I memiliki kendala internal dan eksternal sebagai berikut:

a. Internal : pengiriman Nota Dinas SPT Lebih Bayar (LB) yang lama dari Seksi Pelayanan ke Seksi Pengawasan dan Konsultasi I sehingga menghambat proses penyelesaian. Seksi Waskon I mengetahui adanya SPT LB dari Nota Dinas yang disampaikan Seksi Pelayanan. Atas kendala ini, AR Waskon I mengatasinya dengan rutin menanyakan perihal SPT LB kepada Seksi Pelayanan. Dari pelaksana seksi pelayanan telah mengkonfirmasi bahwa Nota Dinas SPT LB telah dibuat dengan segera di hari kerja berdasarkan tanggal penyampaian SPT oleh Wajib Pajak. Perbedaan waktu penerimaan dan pengiriman ND tersebut dikarenakan adanya birokrasi yang harus dilewati. Mulai dari kepala Seksi Pelayanan, Pelaksana Seksi Waskon I, Kepala Seksi Waskon I, hingga ke AR. 
b. Eksternal : Pemberitahuan rekening oleh Wajib Pajak yang lama, sehingga penerbitan SKPKPP menjadi terburu-buru. Atas kendala ini, AR mencoba menghubungi Wajib Pajak lebih dulu untuk meminta nomor rekening Wajib Pajak.

Seksi Pelayanan memiliki kendala internal dan eksternal sebagai berikut:

a. Internal : saat jatuh tempo pencairan ke KPPN, Kepala KPP sedang berhalangan, misal cuti atau dinas. Hal ini menambah proses baru, yaitu mendaftarkan user pelaksana harian Kepala KPP pada aplikasi SAKTI terlebih dahulu ke KPPN. Untuk mengatasi kendala ini, selama kepala KPP dapat dijangkau, maka pelaksana Seksi Pelayanan menyusul kepala KPP untuk mendapatkan inject in meneruskan pencairan dana ke KPPN.

b. Eksternal : rekening Wajib Pajak tidak aktif. Dalam hal rekening Wajib Pajak tidak aktif, maka dana yang seharusnya dicairkan akan retur secara otomatis. Hal ini menyebabkan SPMKP lama akan dibatalkan dan dihapus, sehingga akan diulang proses penerbitan SPMKP yang baru setelah Wajib Pajak mengaktifkan rekeningnya.

Dalam penerapan proses pengembalian pendahuluan yang dilaksanakan, tidak ada indikasi adanya perlindungan terhadap kas negara demi tercapainya target penerimaan pajak KPP Pratama Bangkinang. Account representative tidak menjadikan nominal lebih bayar sebagai tolak ukur dikabulkannya suatu permohonan. Selama memenuhi ketentuan formal dan material yang ditetapkan, berapa pun jumlah pengajuan permohonan maka akan diproses dan dikabulkan sebagaimana mestinya. Sesuai dengan peraturan yang berlaku bahwa selain batasan khusus jumlah pengajuan pengembalian pendahuluan oleh Wajib Pajak persyaratan tertentu, Wajib Pajak dengan kriteria tertentu dan berisiko rendah dapat mengajukan permohonan pengembalian pendahuluan berapapun jumlahnya dan dapat dikabulkan jika telah memenuhi ketentuan yang ditetapkan.

Pada proses penyelesaian pengembalian pendahuluan yang dilakukan oleh AR Waskon I dan Pelaksana Seksi Pelayanan, terdapat kendala masing-masing pada tahapan yang dilaluinya. Kendala-kendala tersebut telah diatasi dan diminimalisir dengan kebijakan tersendiri yang masih dalam prosedur, sehingga tidak terjadi kelalaian yang menyebabkan kerugian pada negara. Kelalaian yang dapat terjadi misalnya penerbitan SKPPKP yang melebihi batas waktu. Hal ini dapat menyebabkan seluruh nominal lebih bayar atas permohonan pengembalian dapat dikabulkan, meskipun berdasarkan penelitian material nominal pengembalian pendahuluan yang dapat diberikan kurang dari nominal permohonan Wajib Pajak. Atau penerbitan SKPKPP yang melebihi batas waktu sehingga menimbulkan imbalan bunga kepada Wajib Pajak. Berdasarkan wawancara yang dilakukan kepada AR Waskon I, penerbitan SKPPKP dan SKPKPP tidak pernah melebihi batas waktu yang telah ditetapkan.

\section{Kepatuhan PKP Pengembalian Pendahuluan PPN Di KPP Pratama Bangkinang}

Berdasarkan hasil wawancara dengan AR Waskon I, Wajib Pajak yang mengajukan permohonan pengembalian pendahuluan adalah Wajib Pajak yang hampir sama setiap tahun bahkan setiap bulannya. Wajib Pak tersebut kebanyakan merupakan Wajib Pajak yang terdaftar dengan KLU industri minyak kelapa sawit dan konstruksi jalan raya.

Tabel 2 - Permohonan Pengembalian Pendahuluan Kelebihan Pembayaran Pajak

Pengembalian Pendahuluan

\begin{tabular}{ccccc}
\cline { 3 - 5 } No & Tahun & $\begin{array}{c}\text { Jumlah } \\
\text { Permohonan }\end{array}$ & $\begin{array}{c}\text { Jumlah } \\
\text { Disetujui }\end{array}$ & $\begin{array}{c}\text { Jumlah Wajib } \\
\text { Pajak }\end{array}$ \\
\hline 1 & 2018 & 19 & 16 & 4 \\
\hline 2 & 2019 & 16 & 12 & 3 \\
\hline 3 & 2020 & 53 & 11 & 7
\end{tabular}


Sumber : Diolah oleh dari Data Pengembalian Pendahuluan (2021)

Berdasarkan tabel 2, jumlah permohonan pengembalian pendahuluan terbanyak terjadi pada tahun 2020. Pada tahun 2020, hanya 11 permohonan pengembalian pendahuluan yang disetujui dari total sebanyak 53 permohonan. Hal ini menunjukkan bahwa banyak permohonan yang tidak sesuai dengan kriteria ketentuan yang telah ditetapkan sehingga pengembalian pendahuluan ditolak dan ditindaklanjuti melalui mekanisme umum pengembalian kelebihan pembayaran pajak dengan pemeriksaan.

Lonjakan yang cukup tajam pada jumlah permohonan pengembalian pendahuluan di tahun 2020 dikarenakan adanya kebijakan insentif pajak atas pemberian pengembalian pendahuluan berdasarkan Peraturan Menteri Keuangan Nomor 44/PMK.03/2020. Insentif ini diberikan dalam bentuk percepatan restitusi. Hal ini tentu membuat Wajib Pajak berbondongbondong mengajukan permohonan pengembalian pendahuluan kelebihan pembayaran pajak karena dianggap menguntungkan Wajib Pajak dari segi waktu dan materi. Kurangnya literasi dan informasi yang dimiliki oleh Wajib Pajak menyebabkan pengajuan permohonan pengembalian pendahuluan yang tidak sesuai dengan ketentuan insentif pajak maupun pengembalian pendahuluan tanpa insentif pajak. Dengan demikian, permohonan pengembalian pendahuluan yang diajukan Wajib Pajak tidak dapat dikabulkan.

Wajib Pajak yang paling banyak menerima pengembalian pendahuluan juga terjadi di tahun 2020 yaitu sejumlah 7 Wajib Pajak. Dari total keseluruhan Wajib Pajak yang menerima pengembalian pendahuluan pada tahun 2018 hingga 2020, terdapat satu Wajib Pajak yang menerima pengembalian pendahuluan selama tiga tahun berturut-turut dan satu Wajib Pajak yang menerima pengembalian pendahuluan di tahun 2018 dan 2019. Selain itu, salah satu Wajib Pajak yang menerima pengembalian pendahuluan di tahun 2018 telah pindah ke KPP Madya Pekanbaru sejak 2 Januari 2019 berdasarkan keputusan Direktur Jenderal Pajak nomor KEP315/PJ/2018 tentang Pemindahan Wajib Pajak dari kantor Pelayanan Pajak Madya dan KEP316/PJ/2018 tentang Tempat Pendaftaran dan Pelaporan Usaha bagi Wajib Pajak pada Kantor Pelayanan Pajak Madya. Dengan demikian, jumlah Wajib Pajak yang dapat dilihat kepatuhan pelaporan SPT hanya sejumlah 9 Wajib Pajak.

Tabel 3 - Kepatuhan Pelaporan SPT Tahunan dan SPT Masa oleh Wajib Pajak yang

Menerima Pengembalian Pendahuluan

Kepatuhan pelaporan SPT Tahunan

\begin{tabular}{|c|c|c|c|c|c|}
\hline \multicolumn{2}{|c|}{2018} & \multicolumn{2}{|r|}{2019} & \multicolumn{2}{|c|}{2020} \\
\hline $\begin{array}{c}\text { Tepat } \\
\text { Waktu }\end{array}$ & $\begin{array}{c}\text { Tidak } \\
\text { Lapor/Tepat } \\
\text { Waktu }\end{array}$ & $\begin{array}{c}\text { Tepat } \\
\text { Waktu }\end{array}$ & $\begin{array}{c}\text { Tidak } \\
\text { Lapor/Tepat } \\
\text { Waktu }\end{array}$ & $\begin{array}{l}\text { Tepat } \\
\text { Waktu }\end{array}$ & $\begin{array}{c}\text { Tidak } \\
\text { Lapor/Tepat } \\
\text { Waktu }\end{array}$ \\
\hline
\end{tabular}

\begin{tabular}{ccccccc}
\hline Tahunan & 7 & 2 & & & & Terdapat 2 \\
Wajib Pajak \\
yang \\
merupakan \\
Wajib Pajak \\
Cabang
\end{tabular}

\begin{tabular}{|c|c|c|c|c|c|c|c|}
\hline & \multicolumn{6}{|c|}{ Kepatuhan pelaporan SPT Masa PPN } & \multirow[b]{3}{*}{ Keterangan } \\
\hline & \multicolumn{2}{|c|}{2018} & \multicolumn{2}{|c|}{2019} & \multicolumn{2}{|c|}{2020} & \\
\hline & $\begin{array}{c}\text { Tepat } \\
\text { Waktu }\end{array}$ & $\begin{array}{c}\text { Tidak } \\
\text { Lapor/Tepat } \\
\text { Waktu }\end{array}$ & $\begin{array}{c}\text { Tepat } \\
\text { Waktu }\end{array}$ & $\begin{array}{c}\text { Tidak } \\
\text { Lapor/Tepat } \\
\text { Waktu }\end{array}$ & $\begin{array}{c}\text { Tepat } \\
\text { Waktu }\end{array}$ & $\begin{array}{c}\text { Tidak } \\
\text { Lapor/Tepat } \\
\text { Waktu }\end{array}$ & \\
\hline Januari & 6 & 3 & 6 & 3 & 8 & 1 & \multirow{4}{*}{$\begin{array}{c}\text { Terdapat } 1 \\
\text { Wajib Pajak } \\
\text { yang } \\
\text { terdaftar }\end{array}$} \\
\hline Februari & 5 & 4 & 5 & 4 & 6 & 3 & \\
\hline Maret & 5 & 4 & 5 & 4 & 7 & 2 & \\
\hline April & 5 & 4 & 5 & 4 & 8 & 1 & \\
\hline
\end{tabular}




\begin{tabular}{|c|c|c|c|c|c|c|c|}
\hline Mei & 5 & 4 & 6 & 3 & 9 & 0 & \multirow{8}{*}{$\begin{array}{c}\text { pada Juli } \\
2018 \text { dan } \\
\text { dikukuhkan } \\
\text { sebagai } \\
\text { PKP pada } \\
\text { Des } 2018 . \\
\end{array}$} \\
\hline Juni & 5 & 4 & 7 & 2 & 9 & 0 & \\
\hline Juli & 5 & 4 & 7 & 2 & 9 & 0 & \\
\hline Agustus & 5 & 4 & 8 & 1 & 9 & 0 & \\
\hline September & 5 & 4 & 6 & 3 & 9 & 0 & \\
\hline Oktober & 5 & 4 & 7 & 2 & 8 & 1 & \\
\hline November & 5 & 4 & 8 & 1 & 9 & 0 & \\
\hline Desember & 5 & 4 & 8 & 1 & 9 & 0 & \\
\hline
\end{tabular}

Sumber : Diolah dari Master File Wajib Pajak (2021)

Tabel 3 menjelaskan kepatuhan Wajib Pajak yang menerima pengembalian pendahuluan dalam melaporkan SPT Tahunan dan SPT Masa pada tahun pajak 2018 hingga 2020. Tujuh dari sembilan Wajib Pajak telah melaporkan SPT Tahunan dengan tepat waktu, sedangkan sisanya merupakan Wajib Pajak Cabang yang tidak wajib melaporkan SPT Tahunan.

Ketidakpatuhan dalam pelaporan SPT Masa PPN paling banyak terjadi pada tahun pajak 2018 dengan jumlah Wajib Pajak yang tidak lapor atau melaporkan SPT Masa tetapi tidak tepat adalah sebanyak empat Wajib Pajak. Tiga diantaranya adalah Wajib Pajak yang dikukuhkan sebagai Wajib Pajak pada Desember 2018, Juni 2019, dan November 2019. Dengan begitu, pelaporan SPT Masa Pajak Januari hingga November tercatat tiga Wajib Pajak yang tidak memiliki kewajiban melaporkan SPT Masa PPN pada tahun 2018. Sedangkan satu Wajib Pajak lainnya terindikasi tidak memiliki kepatuhan pelaporan SPT Masa PPN sejak masa Januari 2018 hingga April 2019, yang merupakan masa pajak terakhir sebelum Wajib Pajak mengajukan pengembalian pendahuluan. Wajib Pajak tersebut tidak memiliki kesadaran atas kewajiban perpajakannya sehingga ketika terjadi kelebihan pembayaran PPN, Wajib Pajak tersebut memilih mengajukan pengembalian pendahuluan persyaratan tertentu pasal 17D. Hal ini dikarenakan pengembalian pendahuluan Wajib Pajak persyaratan tertentu tidak memiliki ketentuan yang begitu kompleks seperti pengembalian pendahuluan pada pasal 17C yang mempersyaratkan pelaporan SPT secara tepat waktu.

Secara keseluruhan, hanya terdapat satu Wajib Pajak yang memiliki indikasi ketidakpatuhan pelaporan SPT Masa PPN pada tahun pajak 2018 dan 2019. Wajib Pajak tersebut mengajukan permohonan pengembalian pendahuluan Pasal 17D masa pajak Mei 2020 dan telah disetujui. Setelah penerimaan pengembalian pendahuluan tersebut, Wajib Pajak melaporkan SPT Masa PPN pada masa-masa pajak berikutnya secara tepat waktu. Dan pada tahun pajak 2020, ketidakpatuhan Wajib Pajak dalam melaporkan SPT Masa sangat minim terjadi.

\section{Pengembalian Pendahuluan PPN terhadap Penerimaan KPP Pratama Bangkinang}

Jumlah pemberian pengembalian pendahuluan terus mengalami penurunan yang signifikan sejak tahun 2018 hingga tahun 2020, terlihat dari tabel III.3 di bawah ini. Namun hal ini tidak serta merta mempengaruhi pencapaian target penerimaan pajak. Target penerimaan hanya tercapai di tahun 2018 dan 2020.

Tabel 4 - Jumlah Pengembalian Pendahuluan dan Penerimaan Pajak KPP Pratama Bangkinang

\begin{tabular}{ccccccccc} 
& & \multicolumn{2}{c}{ Pengembalian Pendahuluan } & & Target & \multicolumn{1}{c}{$\begin{array}{c}\text { Penerimaan } \\
\text { Netto }\end{array}$} & Pencapaian \\
\cline { 3 - 5 } & Tahun & $\begin{array}{c}\text { Jumlah } \\
\text { Permohonan }\end{array}$ & $\begin{array}{c}\text { Jumlah } \\
\text { Disetujui }\end{array}$ & Total & & Penerimaan & & \\
\hline 1 & 2018 & 19 & 16 & 28.110 .211 .742 & 1.196 .435 .370 .000 & 1.197 .832 .500 .178 & $100,12 \%$ \\
\hline 2 & 2019 & 16 & 12 & 8.727 .203 .931 & 1.495 .464 .984 .000 & 1.129 .328 .293 .286 & $75,52 \%$ \\
\hline
\end{tabular}


Sumber : Diolah dari Data Pengembalian Pendahuluan dan Penerimaan Pajak (2021)

Berdasarkan tabel 4, pada tahun 2018 terdapat pemberian pengembalian pendahuluan yang cukup besar yang mencapai 28 miliar rupiah dengan jumlah permohonan pengembalian pendahuluan yang disetujui sebanyak 16 permohonan. Jumlah pencairan pengembalian dana atas kelebihan pajak ini hanya mengeluarkan dana penerimaan sebesar $2,27 \%$ dari total penerimaan bruto di tahun 2018. Persentase ini sangat kecil dibandingkan dengan total penerimaan pajak yang diperoleh. Di sisi lain, pada tahun yang sama target penerimaan pajak berhasil dilampaui dengan persentase sebesar $100,12 \%$. Pencapaian target penerimaan ini tidak menunjukkan adanya pengaruh yang signifikan atas pemberian pengembalian pendahuluan karena total pemberian pengembalian pendahuluan yang diberikan hanya sebesar $2,27 \%$.

Berbeda dengan tahun 2018, pada tahun 2019 total pemberian pengembalian pendahuluan mengalami penurunan sebesar $68,95 \%$ atau sebanyak 19,3 miliar rupiah. Jumlah pengembalian pendahuluan yang disetujui adalah sebanyak 8,7 miliar rupiah dengan total 12 permohonan. Jumlah pengembalian pendahuluan ini hanya mengeluarkan dana penerimaan sebesar $0,76 \%$ dari total penerimaan bruto. Jumlah pengembalian pendahuluan ini sangat kecil dibandingkan dengan total penerimaan yang diperoleh.

Pada tahun 2019 juga, penerimaan jauh dari target penerimaan yang ditetapkan. Realisasi penerimaan pajak hanya tercatat sebesar 75,52\%. Di samping adanya pemberian pengembalian pendahuluan, terdapat indikasi yang menyebabkan tidak tercapainya target penerimaan pajak. Di tahun 2019, terjadi kenaikan penetapan target penerimaan yang cukup besar dikarenakan pada tahun 2018 target penerimaan berhasil tercapai. Selain itu, pada tahun 2018 terdapat evaluasi pemenuhan kriteria Wajib Pajak yang terdaftar pada Kantor Pelayanan Pajak Madya. Hal ini menyebabkan pemindahan tempat terdaftar dan pelaporan usaha Wajib Pajak per tanggal 2 Januari 2019. Terdapat 24 Wajib Pajak potensial yang sebelumnya terdaftar di KPP Pratama Bangkinang pindah ke KPP Madya Pekanbaru dan 23 Wajib Pajak yang sebelumnya terdaftar di KPP Madya Pekanbaru pindah ke KPP Pratama Bangkinang. Pemindahan ini berdasarkan keputusan Direktur Jenderal Pajak nomor KEP-315/PJ/2018 tentang Pemindahan Wajib Pajak dari kantor Pelayanan Pajak Madya dan KEP-316/PJ/2018 tentang Tempat Pendaftaran dan Pelaporan Usaha bagi Wajib Pajak pada Kantor Pelayanan Pajak Madya. Keputusan tersebut menyebabkan hilangnya potensi penerimaan pajak pada KPP Pratama Bangkinang di tengah tuntutan target penerimaan yang meningkat. Dilihat dari persentase pengembalian pendahuluan dan penerimaan pajak di tahun 2019, pengembalian pendahuluan tidak memberikan pengaruh yang signifikan terhadap penerimaan pajak. Walaupun penerimaan pajak jauh dari target yang ditetapkan, pengembalian pendahuluan hanya mengurangi penerimaan sebesar $0,76 \%$.

Pada tahun 2020, jumlah pengembalian pendahuluan yang diberikan merupakan yang terkecil yaitu hanya sekitar 2 miliar rupiah. Jumlah pengembalian pendahuluan ini hanya mengeluarkan kas negara sebesar $0,20 \%$ dari total penerimaan yang diperoleh oleh KPP Pratama Bangkinang. Jumlah ini sangat kecil dibandingkan dengan penerimaan pajak sebesar 1,3 triliun rupiah. Di samping itu, terjadi penurunan target penerimaan pajak yang cukup signifikan dikarenakan target penerimaan yang tidak tercapai pada tahun 2019. Namun, hal ini nyatanya menjadi motivasi untuk mencapai target penerimaan. KPP Pratama Bangkinang berhasil melampaui target penerimaan dengan realisasi penerimaan neto sebesar 1,3 triliun rupiah atau sebesar $121,45 \%$. Realisasi penerimaan ini merupakan yang terbesar sejak tahun 2018 hingga 2020.

Di samping pemberian pengembalian pendahuluan yang terus menurun, realisasi penerimaan neto cenderung stabil di angka 1,1 triliun rupiah pada tahun 2018 dan 2019 dan meningkat di tahun 2020 menjadi sebesar 1,3 triliun rupiah. Berdasarkan penjelasan di atas, 
pemberian pengembalian pendahuluan hanya memberikan pengaruh pada penerimaan pajak rata-rata sebesar $1,08 \%$ setiap tahunnya. Ada banyak faktor yang mempengaruhi tercapainya target penerimaan pajak baik dari sisi internal maupun eksternal. Dari sisi internal, pencairan tunggakan pajak dengan surat paksa (Nursheha dkk, 2014) dan tingkat kepatuhan wajib pajak dapat memengaruhi penerimaan pajak (Desideria \& Ngadiman, 2019). Selain itu, persepsi kualitas pelayanan juga memiliki kemampuan memengaruhi penerimaan pajak. Semakin baik persepsi Wajib Pajak terhadap kualitas pelayanan maka semakin baik pula tingkat penerimaan pajak yang diperoleh (Cahyono, 2017). Sedangkan dari sisi eksternal, perekonomian secara keseluruhan memengaruhi penerimaan pajak. Peningkatan perekonomian menunjukkan adanya peningkatan produksi barang dan jasa sehingga ikut meningkatkan kegairahan ekonomi. Selain itu, kemiskinan dan kebijakan perpajakan memiliki pengaruh yang signifikan terhadap penerimaan pajak (Handoko dkk, 2014).

\section{PENUTUP}

\section{Simpulan}

Penerapan pengembalian pendahuluan kelebihan pembayaran PPN yang dilakukan di KPP Pratama Bangkinang telah sesuai dengan Peraturan Menteri Keuangan nomor 39/PMK.03/2018 tentang Tata Cara Pengembalian Kelebihan Pembayaran Pajak dan Surat Edaran Direktur Jenderal Pajak nomor SE-10/PJ/2018 tentang Petunjuk Pelaksanaan Pengembalian Pendahuluan Kelebihan Pembayaran Pajak bagi Wajib Pajak dengan Kriteria Tertentu, Wajib Pajak yang Memenuhi Persyaratan Tertentu, dan Pengusaha Kena Pajak Berisiko Rendah. Nilai pengajuan permohonan pengembalian pendahuluan kelebihan pembayaran pajak tidak menjadi tolak ukur diterimanya permohonan. Terkait kendala-kendala yang dihadapi AR Waskon I dan Pelaksana Seksi Pelayanan, dapat dapat diminimalisir dan diatasi secara profesional.

Secara keseluruhan, Wajib Pajak yang menerima pengembalian pendahuluan dan memiliki kewajiban pelaporan SPT Masa PPN memiliki kepatuhan pelaporan SPT Tahunan dan SPT Masa PPN yang tinggi. Hal ini selaras dengan tujuan adanya kebijakan pengembalian pendahuluan yaitu mendorong kesadaran Wajib Pajak untuk patuh menjalankan kewajiban perpajakannya.

Pemberian pengembalian pendahuluan tidak memengaruhi pencapaian target penerimaan pajak secara signifikan atau hanya sebesar $1,08 \%$. Ada banyak faktor lain yang memengaruhi penerimaan pajak.

Pemberian pengembalian pendahuluan kelebihan pembayaran pajak merupakan hak Wajib Pajak yang harus dipenuhi selama sesuai dengan ketentuan. Walaupun penerimaan pajak menjadi poin penting dalam pembangunan nasional, layanan dalam rangka pemenuhan hak Wajib Pajak tetap harus dilaksanakan sebagaimana mestinya.

\section{Saran}

Pada penelitian selanjutnya dapat diteliti lebih lanjut mengenai proses penerapan pengembalian pendahuluan apakah masih relevan dan dapat diterapkan di tengan dengan dinamika peraturan pajak yang kian berkembang.

\section{DAFTAR PUSTAKA}

Anjarwi, A. W., \& Kharisma, L. (2021). Pengaruh Jumlah Percepatan Restitusi Pajak Pertambahan Nilai terhadap Penerimaan pajak Pertambahan Nilai (Studi pada Kantor Pelayanan Pajak Pratama Malang Utara). 1, 120-129

Cahyono, Y. T. (2017). Analisis Faktor-Faktor yang Mempengaruhi Penerimaan Pajak (Studi Empirik di Kantor Pelayanan Pajak Pratama Surakarta). Riset Akuntansi Dan Keuangan 
Indonesia, 2(2), 163-175 https://doi.org/10.23917/reaksi.v2i2.4923

Christoper, A. P., \& Rondonuwu, S. (2016). Pemahaman Ekstensifikasi Wajib Pajak dan Intensifikasi Pajak terhadap Fiskus Tentang Penerimaan Pajak. Jurnal EMBA, 4(1), 12411253

Cindy, J., \& Yenni, M. (2013). Pengaruh Kesadaran Wajib Pajak, Kualitas Pelayanan Fiskus, Sanksi Perpajakan, Lingkungan Wajib Pajak Berada terhadap Kepatuhan Wajib Pajak Orang Pribadi di Surabaya. Tax \& Accounting Review, 1, 51

Darussalam, Septriadi, D., \& Dhora, K. A. (2018). Konsep dan Studi Komparasi Pajak Pertambahan Nilai

Desideria, E., \& Ngadiman. (2019). Faktor-Faktor yang Mempengaruhi Penerimaan Pajak Dari Wajib Pajak Badan Tahun 2016-2017. Jurnal Multiparadigma AKuntansi, I(2), 355-363

Handoko, I., Aimon, H., \& Syofyan, E. (2014). Analisis Faktor-Faktor yang Mempengaruhi Perekonomian dan Penerimaan Pajak Di Indonesia. Jurnal Kajian Ekonomi, 3(05), 103671

Jusmani, \& Qurniawan, R. (2016). Pengaruh Restitusi Pajak Pertambahan Nilai terhadap Penerimaan Pajak Pertambahan Nilai pada Kantor Pelayanan Pajak Pratama Palembang Ilir Barat. Media Wahana Ekonomika, 13(3), 130-142z

Nuraisyah, D. Y. (2019). Analisis Implementasi Peraturan Menteri Keuangan Nomor 39/PMK.03/2018 tentang Tata Cara Pengembalian Pendahuluan Kelebihan Pembayaran Pajak. Universitas Brawijaya

Nursheha, R. A., Suryarini, T., \& Kiswanto. (2014). Faktor-Faktor yang Mempengaruhi Penerimaan Pajak. Accounting Analysis Journal, 3(4), 457-465

Octavia, S., Mayowan, Y., \& Karjo, S. (2015). Analisis Proses Restitusi Pajak Pertambahan Nilai (PPN) di Indonesia. Jurnal Perpajakan (JEJAK), 7(1)

Pamungkas, D. G. (2019). Menyoal Kebijakan "Setengah hati” Restitusi Pendahuluan. MUC Consulting

Republik Indonesia, (2018). Peraturan Menteri Keuangan Nomor 39/PMK.03/2018 tentang Tata Cara Pengembalian Pendahuluan Kelebihan Pembayaran Pajak. Sekretariat Jenderal Kementerian Keuangan

Republik Indonesia, (1983). Undang-Undang Republik Indonesia Nomor 6 Tahun 1983 Tentang Ketentuan Umum Dan Tata Cara Perpajakan Sebagaimana Telah Beberapa Kali Diubah Terakhir Dengan Undang-Undang Nomor 11 Tahun 2020 tentang Cipta Kerja. Sekretariat Negara

Republik Indonesia, (1983). Undang-Undang Republik Indonesia Nomor 8 Tahun 1983 tentang Pajak Pertambahan Nilai Barang Dan Jasa Dan Pajak Penjualan barang Mewah Sebagaimana Telah Beberapa Kali Diubah Terakhir Dengan Undang-Undang Nomor 11 Tahun 2020 tentang Cipta Kerja. Sekretariat Negara

Riftiasari, D. (2019). Pengaruh Restitusi Kelebihan Pembayaran Pajak Pertambahan Nilai Pada Kantor Pelayanan Pajak Pratama Jakarta Penjaringan. Moneter - Jurnal Akuntansi Dan Keuangan, 6(1), 63-68

Silvia, L., Toron, M., \& Hendrawan, A. (2014). Analisis Perubahan Kebijakan Pengembalian Pendahuluan Kelebihan Pembayaran Pajak Kepada Wajib Pajak Yang Memenuhi Persyaratan Tertentu. Universitas Indonesia

Suharyono. (2019). Pengaruh Kesadaran Wajib Pajak dan Pengetahuan Perpajakan Terhadap Kepatuhan Wajib Pajak dalam Membayar Pajak Bumi dan Bangunan di Kabupaten Bengkalis. Inovbiz: Jurnal Inovasi Bisnis, 7, 42-47

Supit, W. M., Saerang, D. P. E., \& Sabijono, H. (2014). Analisis Restitusi Pajak Pertambahan Nilai Terhadap Penerimaan Pajak Pertambahan Nilai Pada Kantor Pelayanan Pajak Pratama Manado. Jurnal Riset Ekonomi, Manajemen, Bisnis Dan Akuntansi, 2(3), 159166 https://doi.org/10.35794/emba.v2i3.5356 